\title{
Conflict and unification in the multilingual landscape of a divided city: the case of Nicosia's border
}

Article

Accepted Version

Themistocleous, C. (2019) Conflict and unification in the multilingual landscape of a divided city: the case of Nicosia's border. Journal of Multilingual and Multicultural Development, 40 (2). pp. 94-114. ISSN 1747-7557 doi:

https://doi.org/10.1080/01434632.2018.1467425 Available at https://centaur.reading.ac.uk/76660/

It is advisable to refer to the publisher's version if you intend to cite from the work. See Guidance on citing.

To link to this article DOI: http://dx.doi.org/10.1080/01434632.2018.1467425

Publisher: Taylor \& Francis

All outputs in CentAUR are protected by Intellectual Property Rights law, including copyright law. Copyright and IPR is retained by the creators or other copyright holders. Terms and conditions for use of this material are defined in the End User Agreement.

www.reading.ac.uk/centaur 
Central Archive at the University of Reading

Reading's research outputs online 


\title{
Conflict and unification in the multilingual landscape of a divided city:
}

\section{The case of Nicosia's border}

\begin{abstract}
The Republic of Cyprus is a country characterised by long-term conflict which resulted in the geopolitical division of the island. Greek-Cypriots and Turkish-Cypriots have lived in separation for more than 30 years until the border re-opened in 2003, allowing people to cross and visit 'the other side'. One of the crossing points is located in the heart of the commercial area in Nicosia, the capital. This study explores the visibility of the two official languages, namely Greek and Turkish, and also English in the multilingual public space near the border. Unlike previous quantitative Linguistic Landscape investigations, this study is using a qualitative Semiotic Landscape approach (Scollon \& Scollon, 2003; Jaworski and Thurlow, 2010) to understand how the public space that divides the two communities interacts with written discourse, visual modalities, spatial arrangements and dimensions of history and culture to create meaning and project ideologies, identities and power relations. The findings show that traditional discourses of separation and conflict are dominant in the public space but at the same time new discourses of unification, peace and integration slowly begin to surface.
\end{abstract}

Keywords: multilingualism, Linguistic Landscape, Geosemiotics, Cyprus, conflict, border 


\section{Introduction}

Although borders are often understood as physical and visible lines separating political, social and economic spaces, they are also practices through which social distinctions are created. According to Newman (2006, 143): 'We live in a world of lines and compartments. We may not necessarily see the lines, but they order our daily life practices...', including our sense of belonging and our identities. Paasi (1999, 670) maintains that boundaries are 'sets of practices and discourses which spread into the whole of society and are not restricted to the border areas'. Borders are usually spaces characterised by multilingualism and language contact, and through this contact issues of language use, ideology and cultural, social and national identity often surface (Carvalho 2014; Watt and Llamas 2014). These issues are often exacerbated in border areas affected by conflict, a theme that according to Watt and Llamas (2014) requires further exploration.

The island of Cyprus has had a turbulent history. Today, the Republic of Cyprus is an independent state yet, due to the long-term conflict between the Greek-Cypriots and the Turkish-Cypriots, it is divided. A border ${ }^{\mathrm{i}}$ separates the country and divides the city of Nicosia in half, making it the only divided capital in Europe. Crossing the dividing line was prohibited in 1974 and since then the two communities had lived in separation until 2003, when movement restrictions were lifted allowing people to visit the 'other side'. One of the seven crossing-points is located in the heart of Nicosia at 
the midpoint of the main commercial street, Ledra, making this district an ideal area to explore issues of multilingualism, borders and conflict.

Ample investigations have been conducted to explore spoken language in communities worldwide, focusing also on how people and media talk about multilingualism (Jaworska and Themistocleous 2018). Yet, less attention has been paid to the written language displayed in public spaces that surround us on a daily basis (Ben-Rafael, Shohamy and Barni 2010). The aim of this study is to explore the use of the two official languages of the Republic of Cyprus (Greek and Turkish) and also English on written signs produced by institutional and private actors located near Nicosia's border. Using the Linguistic Landscape approach I explore the visibility or exclusion of languages in the multilingual landscape and also their spatial and linguistic arrangement to understand the symbolic construction of public space in Nicosia and how this space conveys meanings which may reflect power relations, identities and ideologies.

\section{Linguistic Landscape, multilingualism and conflict}

In their pioneering article, Landry and Bourhis (1997) explain that in order to understand the link between publicly displayed discourse and sociolinguistic reality scholars can explore linguistic objects (e.g. road signs, street names, advertisements, etc.) produced by either institutional or private actors. The terms 'top-down' and 
'bottom-up' have been used in the literature to refer to institutional and private signs respectively (Ben-Rafael, Shohamy, Hasan and Trumper-Hecht 2006). With the development of the field, linguistic objects have been expanded to include verbal texts, images, objects (Shohamy and Waksman 2009), clothes people wear (Coupland 2010), graffiti and street art (Hanauer 2011; Papen 2012; Pennycook 2010) while Sebba (2010) argued that scholars should not only study 'fixed' texts, but also 'ephemeral' ones like stickers, posters, moving texts on busses/trains, and even smells (Pennycook and Otsuji 2015).

The exploration of multilingual communities is the focal point of many Linguistic Landscape investigations. By investigating linguistic objects in multilingual spaces researchers can obtain information about the sociolinguistic composition and language boundaries of a given region (Landry and Bourhis 1997) and also unveil symbolic functions. Kasanga (2015) explains that code choice on public signs is neither neutral nor random; the presence or exclusion of languages in the public arena can restrict the target audience and consequently denote which languages are supported or marginalised by society and language policies. This can provide valuable insights into the prominence, status and prestige of languages and into ideological conflicts, especially in areas which are politically and socially contested. (Ben-Rafael et al. 2010; Lado 2011; Marten, Van Mensel and Gorter 2012; Rubdy and Ben-Said 2015; Shohamy 2006). 
Research exploring the Linguistic Landscape in areas of conflict is a growing field. In one of the earliest studies Ben-Rafael et al. (2006) investigated the Linguistic Landscape of Israel which is affected by the on-going Jewish-Palestinian conflict. They considered the degree of visibility of Israel-Hebrew, Arabic and English in various Israeli cities and found differing patterns of Linguistic Landscape in each community, which they explain might reflect complex power relations and influences of modernity and globalisation. Trumper-Hecht (2009) also considered the case of Israel looking at the use of Arabic on public signs in mixed cities. Trumper-Hecht (2009) argues that the language battle between Hebrew and Arabic reflects the wider struggle between the two national groups. Pavlenko (2009) probed the Linguistic Landscape of post-Soviet countries, focusing on changes since 1991 when many countries adopted desovietisation policies to distance themselves from Russia and develop distinct national identities. While the Linguistic Landscapes of countries like Moldova, Ukraine, Latvia, and Kyrgyzstan exhibit "derussification" and "de-sovietization" (Pavlenko 2009), Russian is still used in the self-declared Republic of Transnistria as it is considered 'a formative aspect of its cultural and political identity and a bulwark against cultural and political change' (Muth 2014, 26). Rubdy and Ben Said (2015) present additional case studies exploring conflict and exclusion in different multilingual contexts ranging from Mumbai, to America, Taipei, Congo and even cyberspaces. 


\section{Linguistic Landscape: Analytical and theoretical perspectives}

Early Linguistic Landscape studies mainly explored the visibility of languages using quantitative methods. Researchers analysed the distribution of languages in the Linguistic Landscape of multilingual communities by categorising signs as top-down or bottom-up (see studies in Gorter 2006). Findings from the studies reported in Gorter (2006) suggest that compared to official signs, non-official ones tend to represent more accurately the multilingual reality of an area.

With the development of the field some scholars turned their interest to qualitative and ethnographic approaches, arguing that counting signs alone might not provide insights on authorship and readership and motivations to display or omit languages. Blommaert (2013) has promoted quantitative methods as a first step but argues that ethnographically- and discourse-oriented research needs to be adopted to better understand the socio-cultural meanings of signs.

Scholars have also begun to look more deeply not only into the textual components of signs but also into visual discourse, emplacement, communicative intent and dimensions of history and culture. Scollon and Wong Scollon's (2003) geosemiotics framework and, in particular the idea of place semiotics, focuses on the study of discourses in public space via the placement of signs in the material world. This framework builds upon Kress and Van Leeuwen's (1996) grammar of visual 
design and offers an excellent analytical approach to uncover the ways in which space generates meaning. Three aspects can be considered when analysing signs: 1) code preference system, 2) inscription system, and 3) emplacement system. The code preference system relates to code choice within a given sign, especially when it comes to bi-multilingual signs. According to Scollon and Wong Scollon (2003), a choice system is created by the mere fact that languages in bi-multilingual signs cannot be displayed simultaneously in the same position. Prioritising a given language can index its prominence, status and prestige, and consequently project ideological stances relating to power relations within a given community. The inscription system deals with the use of fonts, visual modalities and materials on which the texts are written. Finally, the emplacement system is concerned with where in the physical world a sign is located. According to Scollon and Wong Scollon (2003) signs generate their meaning depending on how and in which particular location they are positioned. Here the concept of 'space' is of major importance and therefore requires further theorising.

A non-essentialist view of space, traced back to the work of Lefebvre (1991), has attracted scholars from a broad spectrum of disciplines including sociolinguistics (Jaworski and Thurlow 2010; Lou 2016; Norris and Jones 2005; Papen 2012). This theory sees space not just as something physical, but as a social construct. The concept of spatialisation has been introduced in the literature to refer to the processes by which space is constructed, represented, organised and experienced (Jaworski and Thurlow 
2010: 7). Spaces are socially constructed through various processes including people's sense, experiencing and sharing of space, feeling of belonging or being excluded from it and interacting with others within it. These processes can lead to identity building (Johnstone 2004). In addition, Blommaert (2013) maintains that public signs can also represent and organise the space in which they operate. As mentioned in section 2, signs in public spaces are never neutral; they always display connections to social structure, power, hierarchies, culture as well as ideologies. Space (an abstract concept) becomes place once people get to know it better and endow it with value (Tuan 1977). It can therefore be seen as a semiotic resource; a sphere of social and cultural practice in which visible inscriptions, made through deliberate human intervention, construct the space and generate meaning (Jaworski and Thurlow 2010, 2). Another important aspect that needs to be taken into consideration is that spaces are not static; public spaces need to be conceived as a contested and constantly changing arena (Papen 2012; Shohamy, Ben-Rafael and Barni 2010). Through time space changes as new shops emerge, developments are made, new signs appear or old signs disappear. Its investigation is therefore crucial as it enables us to understand aspects of social change.

\section{The Republic of Cyprus: A history of conflict}

The island of Cyprus has been inhabited since the early 12th century BC by the Mycenaeans. Various other settlers occupied the island one of which were the Ottomans who remained in Cyprus for about 300 years (1571-1878) (Tofallis 2016). Following 
the Ottoman rule, the island became part of the British Empire (1878-1960) and according to Marangou and Coutas (2011) this was the period when the commercial centre within walled Nicosia developed and flourished. The 'Liberation Struggle' against the British colonial rule took place in 1955-1959 and after gaining its independence the Republic of Cyprus was declared an independent state in 1960 (Mallinson 2009).

The years that followed were turbulent with political unrest resulting to significant ideological nationalism and hostility among the Greek-Cypriots and TurkishCypriots (Mallinson 2009). In 1963 intercommunal fighting began and the unrest escalated to a war in 1974, which resulted in the geopolitical separation of the island; Greek-Cypriots were displaced to the south part of the island, Turkish-Cypriots to the north $^{\text {ii }}$ and a buffer zone (Green Line), controlled by the UN peacekeeping force, separated the two communities (Mallinson 2009). Ledra Street was divided by a bricked wall and suffered a sharp decline in resident population, struggling to remain a busy commercial centre (Karageorghis 2011).

In 1983 the Turkish-Cypriots self-declared the independent 'Turkish Republic of Northern Cyprus' (TRNC), a state recognised only by Turkey (Mallinson 2009). The Republic of Cyprus joined the EU in 2003 and in April 2003 Turkish-Cypriots agreed to ease travel restrictions allowing people to cross the dividing line for the first time after 30 years (Karageorghis 2011). Since then, the Ledra checkpoint (Figure 1) became a 
busy crossing point ${ }^{\mathrm{iii}}$. This change boosted the economic prospects of the area and after decades of abandonment, urban revitalisation begun to take place with the help of UN and EU programmes. The centre of Nicosia's old town underwent serious renovations and the old town became once again a busy commercial centre. Recent political developments have seen the current leaders, who have both been vocal advocates of reconciliation, attending further talks. However, no solution to the 'Cypriot Problem' has been reached yet.

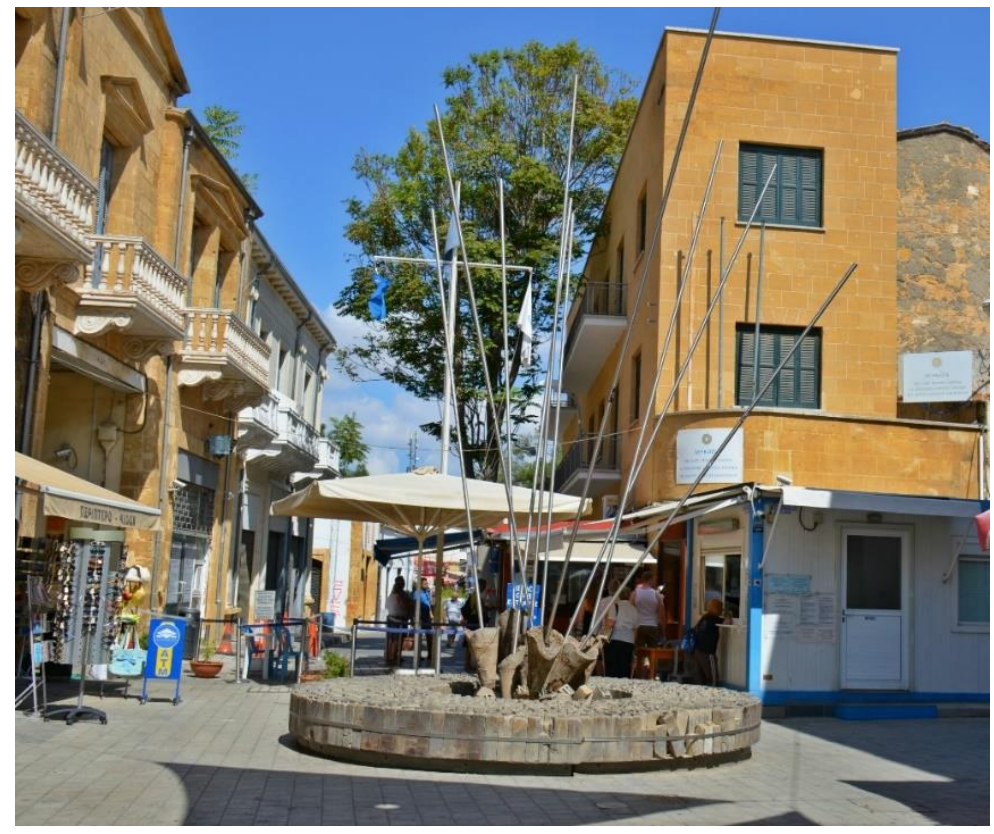

Figure 1. Ledra street checkpoint in the Greek-Cypriot community. 


\section{Language policy, ideologies and identities in Cyprus}

The linguistic repertoire of the two ethnic communities consists of a local dialect (Cypriot-Greek or Cypriot-Turkish) which are mainly used for everyday oral communication $^{\mathrm{iv}}$ and the respective standard language (Standard Modern Greek or Standard Turkish) which is learnt through formal education and it is used for written purposes. Communication between the two ethnic groups is scarce, thus bilingualism in Greek and Turkish is limited (Hadjioannou et al. 2011). Each language is considered an essential pillar for the maintenance of each community's ethnic identity (KaroullaVrikkis 2010) therefore when Cyprus was declared an independent state in 1960, the Constitution safeguarded the linguistic equality between the two ethnic languages by recognising both as official languages (Karyolemou 2003). Both languages appear in public documents and Turkish is obligatorily present under Greek in government buildings of the Republic of Cyprus. English, the language of the former British colonial rule, remained dominant and it was considered as an unofficially-official third, neutral language, which was neither ethnic nor mother tongue (Karoulla-Vrikkis 2010). English continued to be used in the court and civil service until 1988 and today it is used alongside Greek and Turkish in official documents (Karoulla-Vrikkis 2010). It is also widely-spoken in Cyprus and used for interethic communication, business and tourism. It should be noted that only Turkish was recognised as the official language of the self-declared TRNC in 1983. 
Karoulla-Vrikkis (2010) explains that two ideological positions exist among Greek-Cypriots: Hellenisation vs. Cypriotisation. The former endorses a 'Greek national identity' through the promotion of a common religion, culture and language with Greece. English is seen as a threat to Greekness and a distortion of the Greek language. Cypriotisation on the other hand fosters an independent 'Cypriot national identity', promoting the use of Greek and Turkish as official languages as well as English, due to its use on the island during the British rule and its associations with globalisation and modernity. Akçalı (2011) and Kizilyürek and Gautier-Kizilyürek (2004) discuss similar identity shifts within the Turkish-Cypriot community which is also battling between a Turkish and Cypriot identity.

These language ideologies have influenced language policy in the Republic of Cyprus, especially in relation to education. Karoulla-Vrikkis (2010) and Karyolemou (2003) report heated debates about the language of instruction of the newly founded University of Cyprus; Greek and Turkish were finally adopted (Hadjioannou et al. 2011). A recent development saw the language of 'the other' being introduced as a foreign language into the public education of both communities in 2003. Although this was an emblematic gesture to end hostility between the two ethnic groups, it was seen by some with suspicion and was described as teaching the 'language of the enemy' (Charalambous, Charalambous and Rampton 2017). Tum, Kunt and Kunt (2015), 
however, report positive attitudes from Turkish-Cypriot students towards learning Greek language and culture.

It is clear that ethic identities and ideologies play a crucial role when it comes to language use in Cyprus and have undoubtedly influenced language policies. It is interesting therefore to explore how these identities, ideologies and power relations are manifested in the public space, an area of investigation that, with the exception of a few studies, has received relatively less attention.

\section{Exploring multilingualism in Cyprus}

Recent data from the 2011 census indicate that Cyprus has been attracting inward migration over the last decades mainly from Europe, South Asia, Middle East and Africa (CYSTAT 2011). At the same time mobility among the two local ethnic communities has also been enhanced by opening the border in 2003. These developments which have significantly changed the demographic character of the island have attracted the interest of scholars who begun to explore aspects of multilingualism on the island (Antoniou and Katsos 2017; Nicolaou et al 2016; Pavlenko 2017).

The exploration of the public space in Cyprus has also attracted the interest of scholars. Karoulla-Vrikkis $(2013 ;$ 2016) looked at the use Greek and English in public and commercial signs in Nicosia's city centre, looking at policy debates aiming to regulate language use in public space. Tsiplakou (2017) investigated instances of 
graffiti in Nicosia and identified the usage of Greek (including the Cypriot-Greek dialect), English, Turkish, French and Latin as well as instances of code-mixing, ungrammatical structures and subversions of formal writing conventions. In another study, Eracleous and Pavlenko (2012) explored the use of Russian in Cyprus' second largest city, Limassol.

While these studies are enlightening, none of them focuses explicitly on the use of the two official languages in Cyprus and how code choices between Greek and Turkish and English, the neutral, global language, may reflect ideologies and power relations between the two local ethnic communities. The present study therefore endeavours to fill this research gap.

\section{Data collection}

Photographic data was collected from August 2016 to January 2018. The Old Town in Nicosia was chosen for investigation because of its proximity to the border and also because it is a busy commercial area that attracts people from both ethnic communities. In the Greek-Cypriot community data was collected from the following streets: Ledra, Onasagorou, Nikokleous, Stoa Papadopoulou, Sokratous, Lykourgou, Arsinois, Stoa Klokkari and Ippokratous (see map in Figure 2 below). In the Turkishoccupied area data was collected from the rest of Ledra Street (known as Lokmaci sokak in Turkish) and from the following streets: Siret Bahçeli, Kadinlar Pazari and Arasta leading to Büyük Han and the Selimiye Mosque. Data was also collected from 
the border area and the UN-controlled buffer zone after obtaining the permission from the local authorities. This area was also chosen for investigation as on the one hand it is a neutral space that divides the two communities, and on the other hand it also offers a portal (Kallen 2010) that functions as an exit and entrance from one linguistic, cultural and physical environment to another.

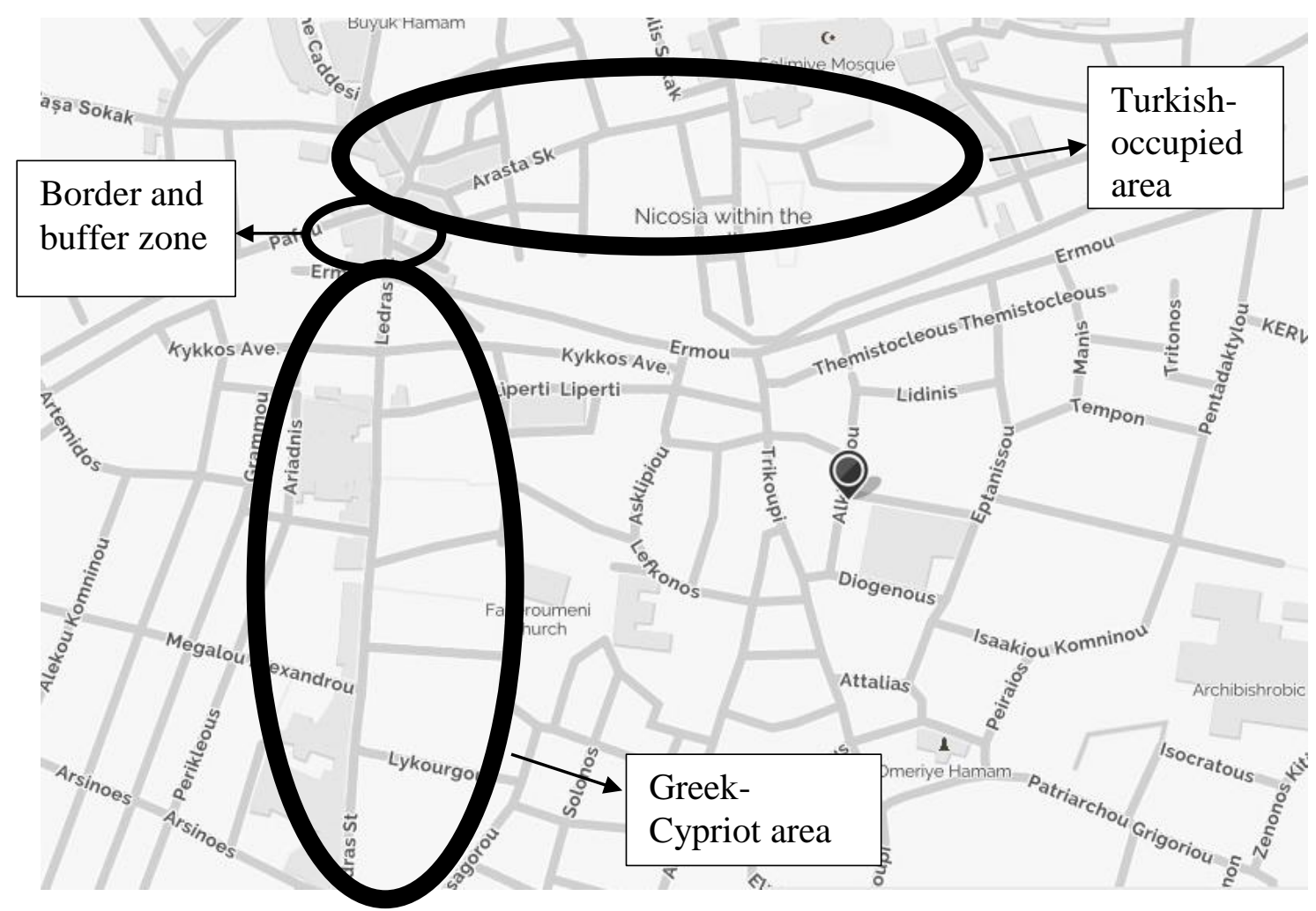

Figure 2. Map of Nicosia 
The entire length of the above mentioned streets was documented and each sign visible and legible to passers-by was photographed. In total, 1166 signs form the sample of this study. Table 1 below shows the languages identified.

\begin{tabular}{|l|c|c|c|c|c|c|}
\hline Language(s) & \multicolumn{2}{|c|}{$\begin{array}{c}\text { Greek-Cypriot } \\
\text { community }\end{array}$} & \multicolumn{2}{c|}{$\begin{array}{c}\text { Border \& Buffer } \\
\text { zone }\end{array}$} & \multicolumn{2}{c|}{$\begin{array}{c}\text { Turkish-occupied } \\
\text { area }\end{array}$} \\
\hline & N & \% & N & \% & N & \% \\
\hline English & 514 & 56.36 & 18 & 38.30 & 86 & 41.75 \\
\hline Greek & 198 & 21.71 & 6 & 12.77 & 1 & 0.5 \\
\hline Turkish & - & 0 & 4 & 8.5 & 64 & 30.97 \\
\hline English \& Greek & 180 & 19.73 & 4 & 8.5 & - & 0 \\
\hline English \& Turkish & 1 & 0.11 & 6 & 12.76 & 47 & 22.85 \\
\hline Greek \& Turkish & 1 & 0.11 & 3 & 6.4 & 3 & 0.99 \\
\hline $\begin{array}{l}\text { English, Greek \& } \\
\text { Turkish }\end{array}$ & 1 & 0.11 & 5 & 10.63 & 4 & 1.94 \\
\hline $\begin{array}{l}\text { English \& other } \\
\text { language }\end{array}$ & 6 & 0.66 & - & 0 & - & 0 \\
\hline $\begin{array}{l}\text { English, Greek, } \\
\text { Turkish \& other } \\
\text { language }\end{array}$ & - & 0 & - & 0 & 1 & 0.5 \\
\hline $\begin{array}{l}\text { English, Greek \& } \\
\text { other language }\end{array}$ & 6 & 0.66 & - & 0 & - & 0 \\
\hline Other language & 5 & 0.55 & 1 & 2.14 & 1 & 0.5 \\
\hline Total & $\mathbf{9 1 2}$ & $\mathbf{1 0 0}$ & $\mathbf{4 7}$ & $\mathbf{1 0 0}$ & $\mathbf{2 0 7}$ & $\mathbf{1 0 0}$ \\
\hline Table 1: Languagen & & & & & & \\
\hline
\end{tabular}

Table 1: Languages identified in the Linguistic Landscape of Nicosia's old town.

*Other languages include Italian, Russian, Romanian, Arabic, Filipino and French. 
The findings indicate that in the Greek-Cypriot community English is the dominant language (56.36\%), followed by monolingual signs in Greek $(21.71 \%)$ and bilingual signs in English and Greek (19.73\%). The pattern is similar in the Turkishoccupied area (English 41.75\%, monolingual Turkish 30.97\%, bilingual English and Turkish $22.85 \%$ ). The language of 'the other' is mostly excluded from the Linguistic Landscape of each local community with only a few instances of Greek found in the Turkish-occupied area and Turkish in the Greek-Cypriot community. Data from the border and buffer zone area is interesting as usage of both official languages on public signs was higher.

In the section that follows, I analyse representative top-down signs from each community to explore how local governments and language policies influence language usage on public signs. Official signage is often devoted to the activities of the state and their production is usually determined by government regulations (Shohamy et al 2010). Seeing that language patterns differ in the border and buffer zone, I also analyse topdown signs from there in order to grasp language usage in this neutral area. I then explore bottom-up signs from the marketplace; according to Coupland (2010) although this type of signs are often produced outside institutional policies and the civil authority, they might still be ideologically triggered. Finally, I analyse instances of ephemeral signs including posters, stickers and graffiti as according to Sebba (2010) and 
Pennycook (2010) such signs are important parts of the Linguistic Landscape and also contribute to the creation of meaning and projection of ideologies.

\section{Analysis}

\section{Official signs}

The street name signs in Figures 3 and 4 are from the Greek-Cypriot and the TurkishCypriot community respectively. In terms of visual semiotics both signs meet similar conventions of size, shape and colour (i.e. white letters on blue background). Also, when it comes to their emplacement both are mounted high at the corner of a building, identifying the relevant street. The emplacement of codes within the signs is interesting as in both cases the language of 'the other' is excluded. Following the monolingual language policy of the self-declared TRNC, only Turkish is displayed on the street name signs in this area, targeting therefore only audiences who are familiar with this language. The street name signs found in the Greek-Cypriot community are bilingual in Greek and English. Greek is prioritised occupying top position while English is in secondary position at the bottom. The target audiences are Greek speakers and also anyone who is familiar with English, including English speakers from TRNC. The language choice in these signs provides spatial representation of the two ethnic groups and their language in each community respectively but, at the same time, the exclusion of the language of 'the other' indexes an ideology of political, cultural and social separation. 


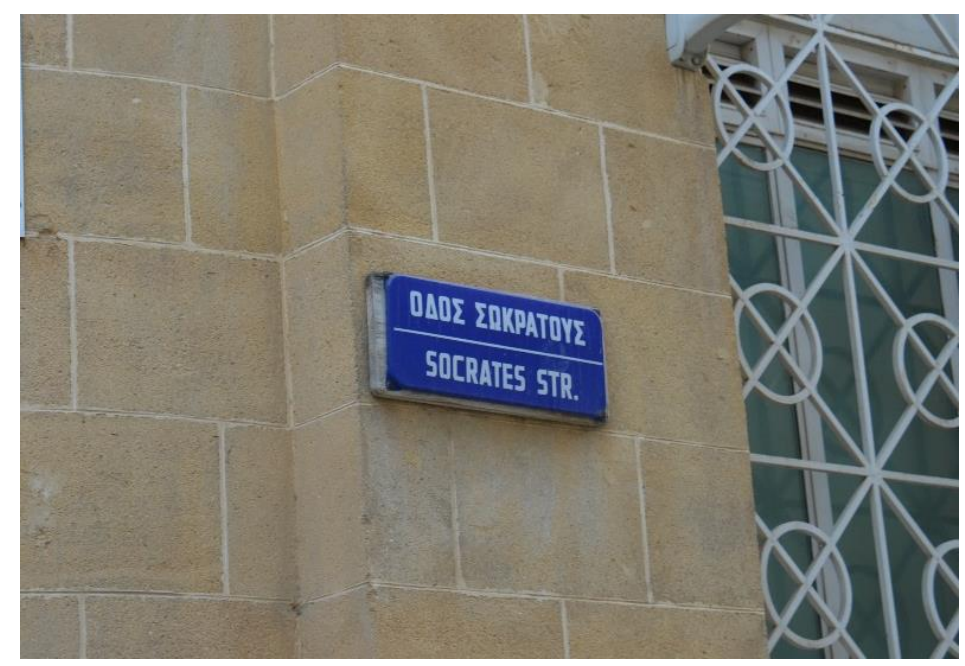

Figure 3. Street name sign in Greek-Cypriot community.

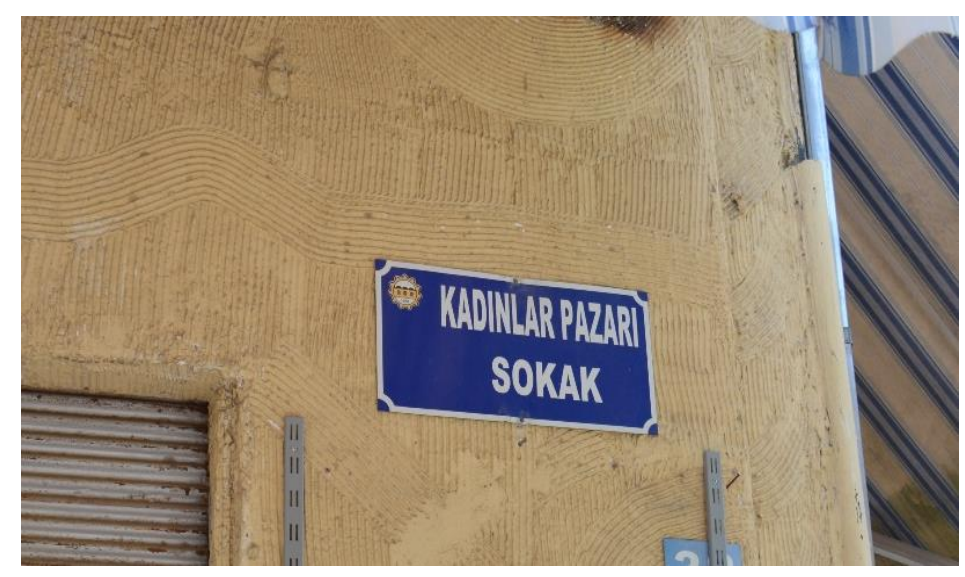

Figure 4. Street name sign in Turkish-Cypriot community.

A street name sign was also found in the buffer zone (Figure 5a). Its size, shape and colour meet the same conventions with the signs discussed above however other elements are also included. The phrase 'European Union Committee of the Regions' is displayed in top position and the EU insignia at the top right; this suggests that the EU 
has been involved in the creation of the sign. This not surprising as this sign is located in the UN-controlled zone, which has been restored using funds from the EU. Other lexical elements include the words 'Open' (left) and 'Street' (bottom right) - reading 'Open Ledra Street'. As mentioned in section 4, Ledra Street is currently divided and access is restricted. Creating a sentence by incorporating the word 'Open' to the street name, this sign acts as a reminder which suggests that finding a solution to the Cypriot problem will remove barriers and consequently enable free access throughout the whole length of this street. This sign promotes discourses of unification, peace and integration, qualities which are promoted by the EU and the UN. The emplacement of this sign in the physical world is significant for the promotion of this ideology. The sign is located in the middle of the buffer zone, placed on small purpose-made sign poles instead of being mounted high on a wall (Figure 5b) making it impossible for passers-by to miss it.

This was the only trilingual street name sign found in the area. Regarding the emplacement of codes, English occupies a central role because it is set as a framework since it appears in three of the four sides of the sign (up - up left - down right). Its place in-between Greek and Turkish is symbolic because English is an ideologically neutral language in Cyprus compared to the two ethnically heavily marked languages. The two official languages of the Republic of Cyprus (the officially recognised state) are also included. As mentioned in section 5, language policy in the Republic of Cyprus recommends that Turkish follows Greek, therefore the order of the languages here 
seems to follow this recommendation, placing Greek (the language of the majority) first and Turkish (the language of the minority) second.

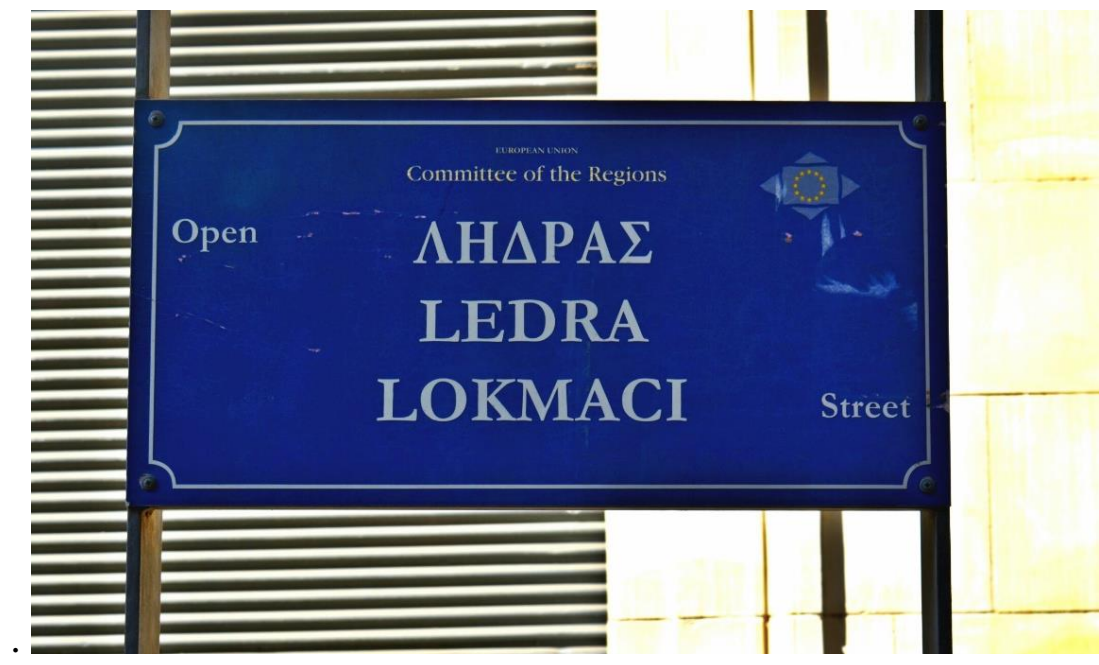

Figure 5a. Street name sign in the buffer zone.

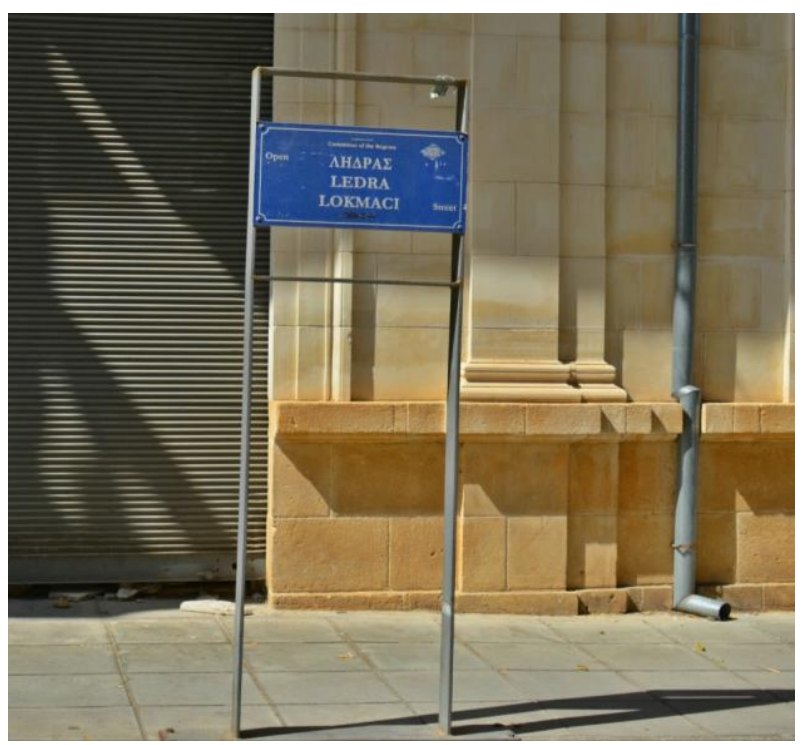

Figure 5b. Street name sign in the buffer zone. 
A number of warning signs become visible when one comes closer to the checkpoints of each community. The notification in Figure 6 is trilingual. In terms of emplacement in the physical world this sign is located next to the Turkish-Cypriot checkpoint therefore Turkish, the only official language of the self-declared TRNC, is prioritised followed by English, the international and neutral language, and then by Greek, the language of 'the other', which is displayed last. Visual elements include the Turkish insignia (a red star and crescent similar to the Turkish flag) at the top and the phrase 'Polis Genel Müdürlüğü' ('Police General Directorate') at the bottom right, to which translation is not provided, restricting therefore the audience to Turkish-speakers only. The warning signs in Figure 7 are also trilingual. Being placed near the GreekCypriot border and also produced by the Republic of Cyprus, these signs present Greek first, followed by Turkish and then by English, respecting therefore the language policy guidelines and the provisions of the Constitution of the Republic of Cyprus. The function of both signs is to notify people of immigration controls, nevertheless at the same time they provide information about the social composition and the language boundaries of the areas that people who cross the border are exiting and entering. Both signs promote discourses of tolerance by incorporating the language of 'the other', but also they are symbolic as each gives prominence to its own ethic language. The order of appearance reflects the power relations between the two communities which link to 
processes of political legitimation, an issue which has always been of primary importance in the struggle between the two communities.

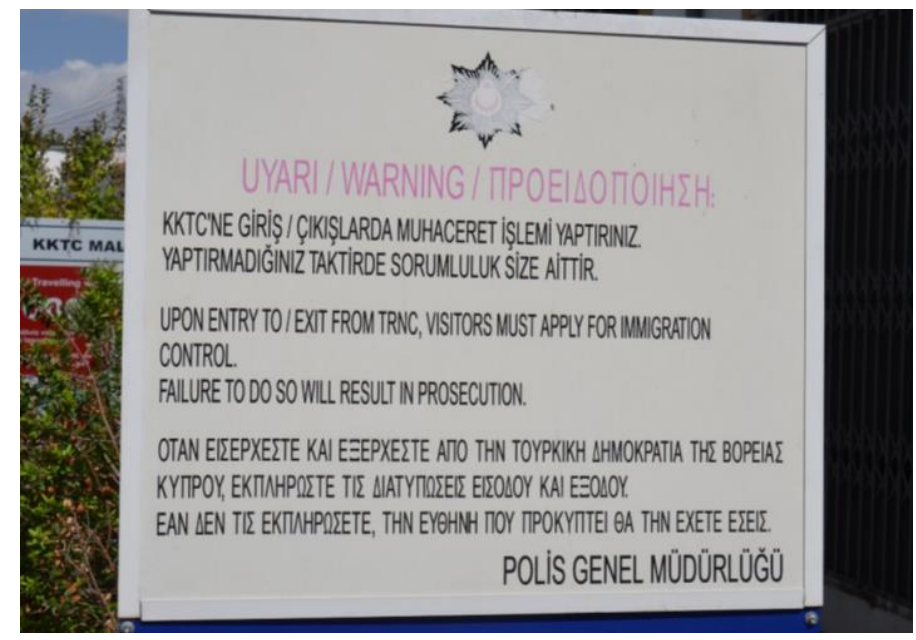

Figure 6. Warning sign at the Turkish-Cypriot checkpoint.

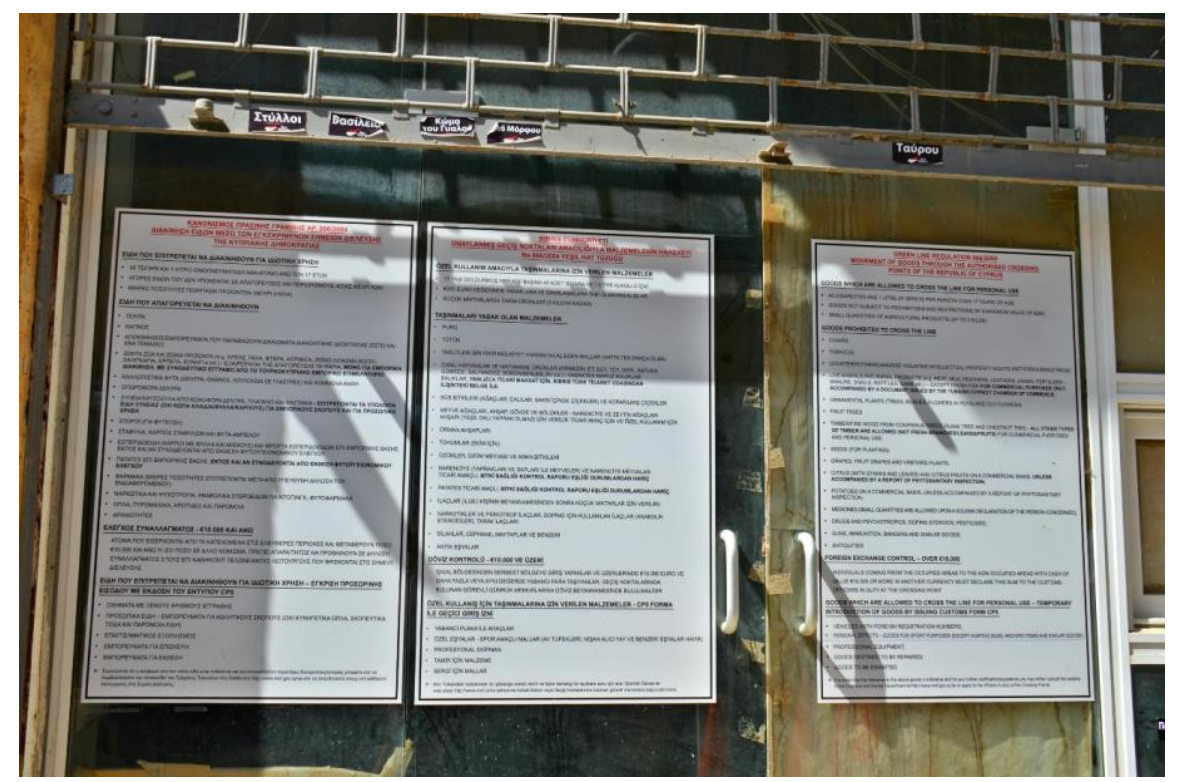

Figure 7. Warning sign at the Greek-Cypriot checkpoint. 
Not all signs in the buffer zone are trilingual. Figure 8 shows a warning sign which was located in front of the regulation sign discussed in Figure 7, near the GreekCypriot checkpoint. Turkish is excluded. The same happens in Figure 9, which shows a sign located at the Turkish border, wishing 'Good Bye' to those who visited this area. In this case, Greek is excluded. Finally, it was interesting to observe that someone placed various stickers above and next to the trilingual sign in Figure 7 which show the island of Cyprus divided in two, with the Turkish-occupied area in red (the colour associated with Turkey) and on top names of villages that are now under Turkish occupation (Figure 10). In addition, the stickers bear the well-known, among Greek-Cypriots message, ' $\Delta \varepsilon v \xi \varepsilon \chi v \omega ́$ ' (I don't forget), referring to what was lost after the war. The images, colours, text as well as the emplacement of these stickers above and next to the trilingual warning sign in Figure 7, which tolerates and incorporates the language of 'the other', is interesting as they act as reminders to those who approach the GreekCypriot checkpoint of the conflict and division. It can be argued therefore that beyond the few trilingual official signs located near the checkpoints and the buffer zone, the language of 'the other' is mainly excluded from other top-down signs, promoting once again discourses of separation. 


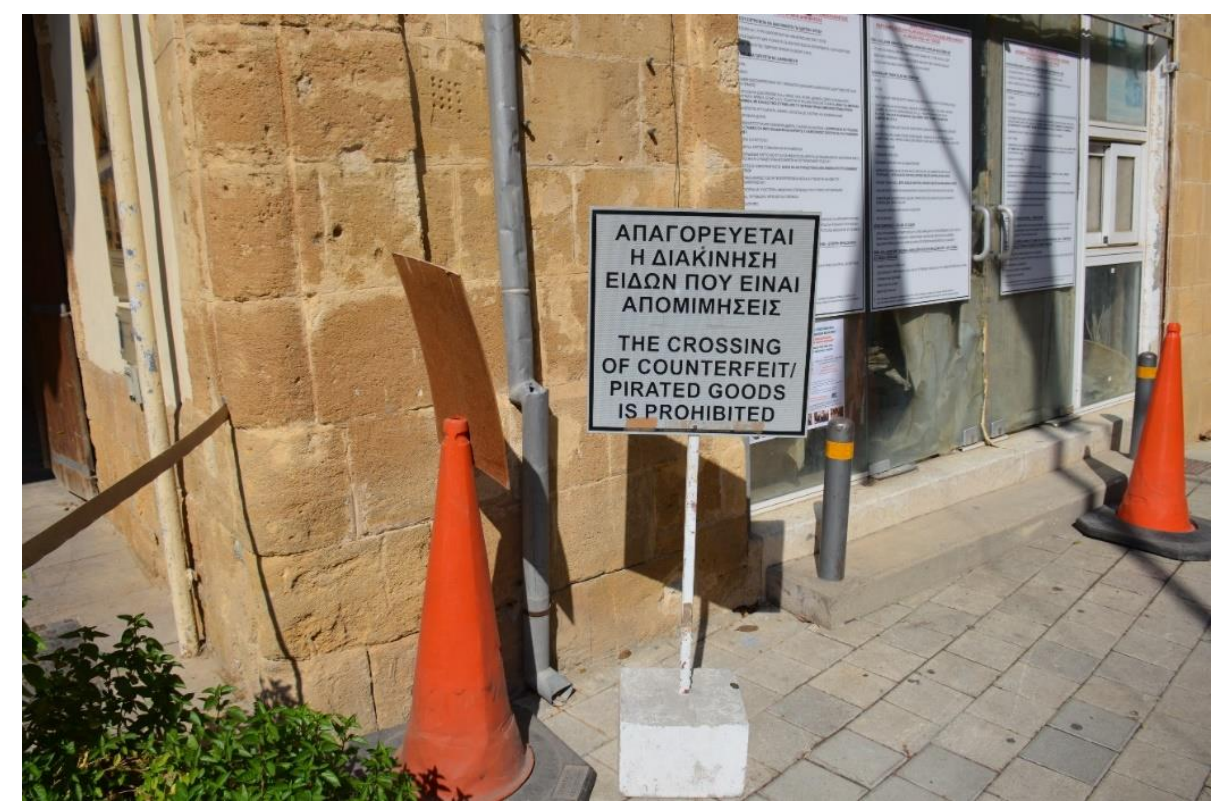

Figure 8. Warning sign near the Greek-Cypriot checkpoint.

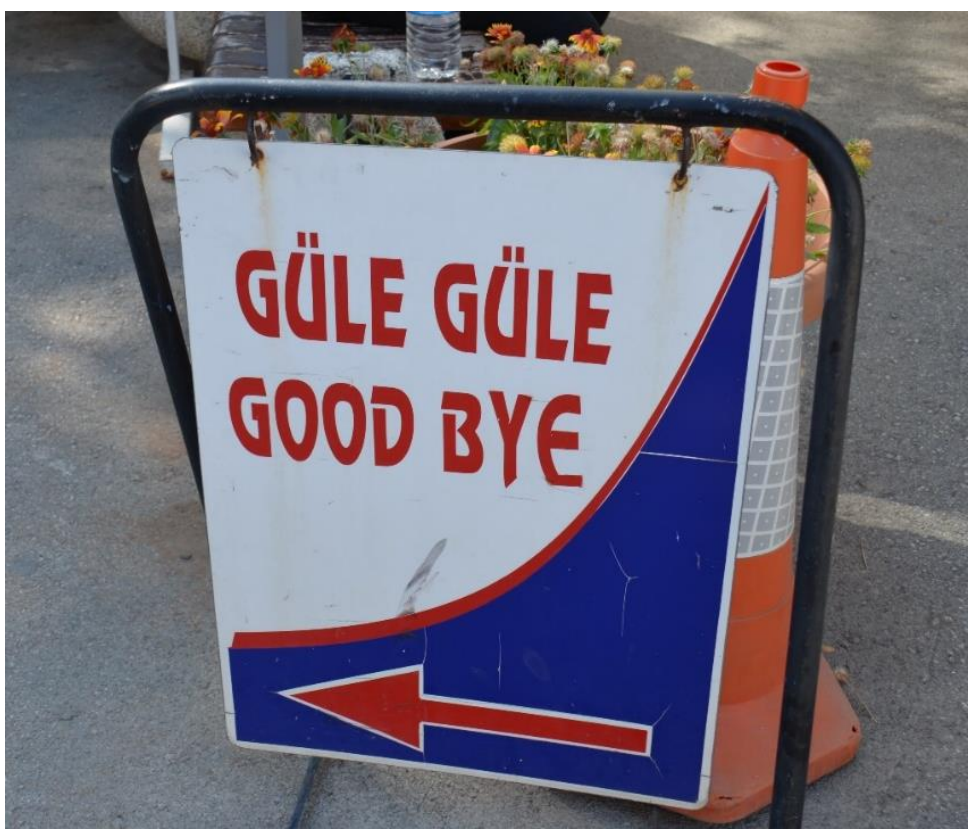

Figure 9. Greeting sign near the Turkish-Cypriot checkpoint. 


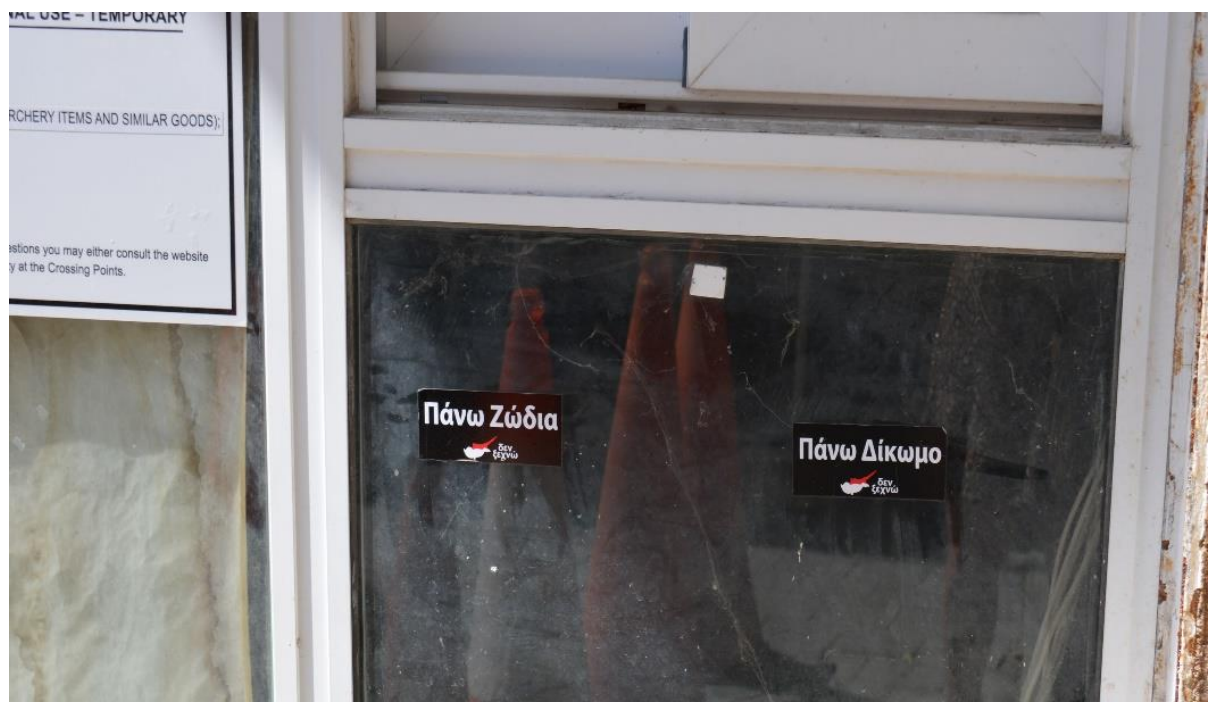

Figure 10. Stickers of divided Cyprus near the Greek-Cypriot checkpoint.

\section{The marketplace}

During my fieldwork in the Greek-Cypriot community, I observed that almost all shop signs and advertisements are in Greek and/or English. Turkish is almost exclusively absent from the Greek-Cypriot marketplace, which could be ideologically driven and linked to the historical, political and cultural differences. This absence enhances a sense of alienation and promotes discourses of separation and conflict. There was however one advertisement which contained English and Turkish (Figure 11a). The sign advertises electronic cigarettes and is mainly dominated by pictures and logos. The English sentence 'Electronic cigarette products are sold within this shop' displayed at the bottom left is followed by a Turkish translation (Figure 11b). The location of this sign in the physical world could be relevant to the code choice and inclusion of Turkish; 
the sign was found outside a small convenience shop, located right next to the border, targeting therefore Turkish-speakers who enter the Greek-Cypriot community. The fact however that the Turkish translation is displayed at the bottom left in small font makes it less visible, so although the language of 'the other' is included, it is done almost in disguise.

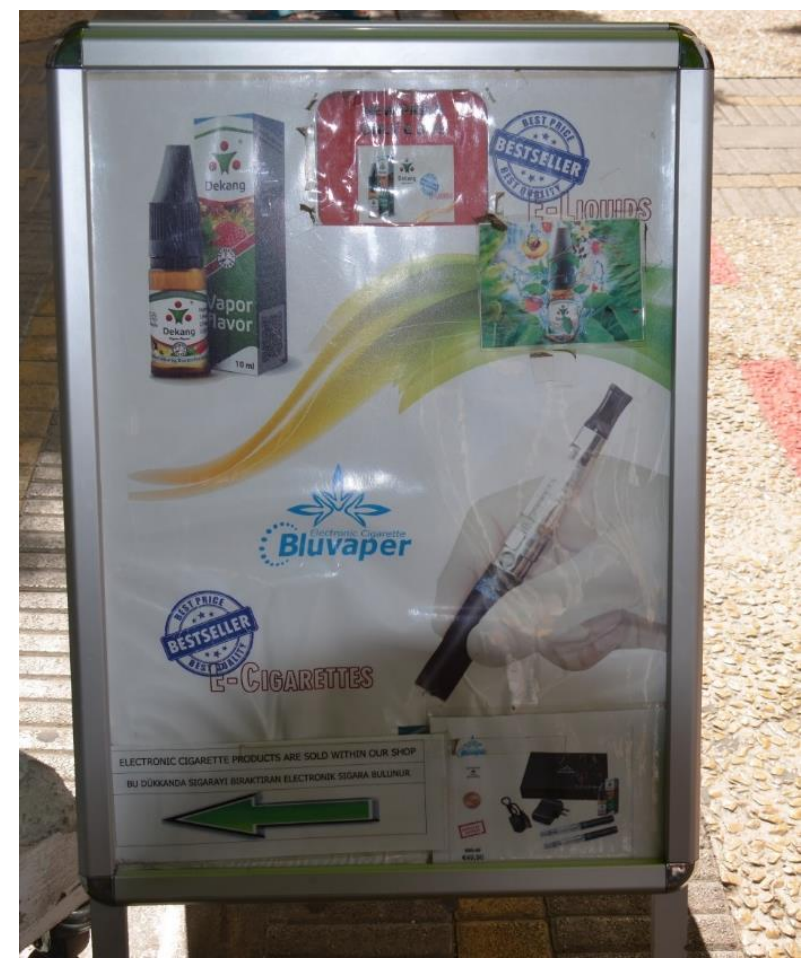

Figure 11a. Advertisement board at Ledra Street in Greek-Cypriot community. 


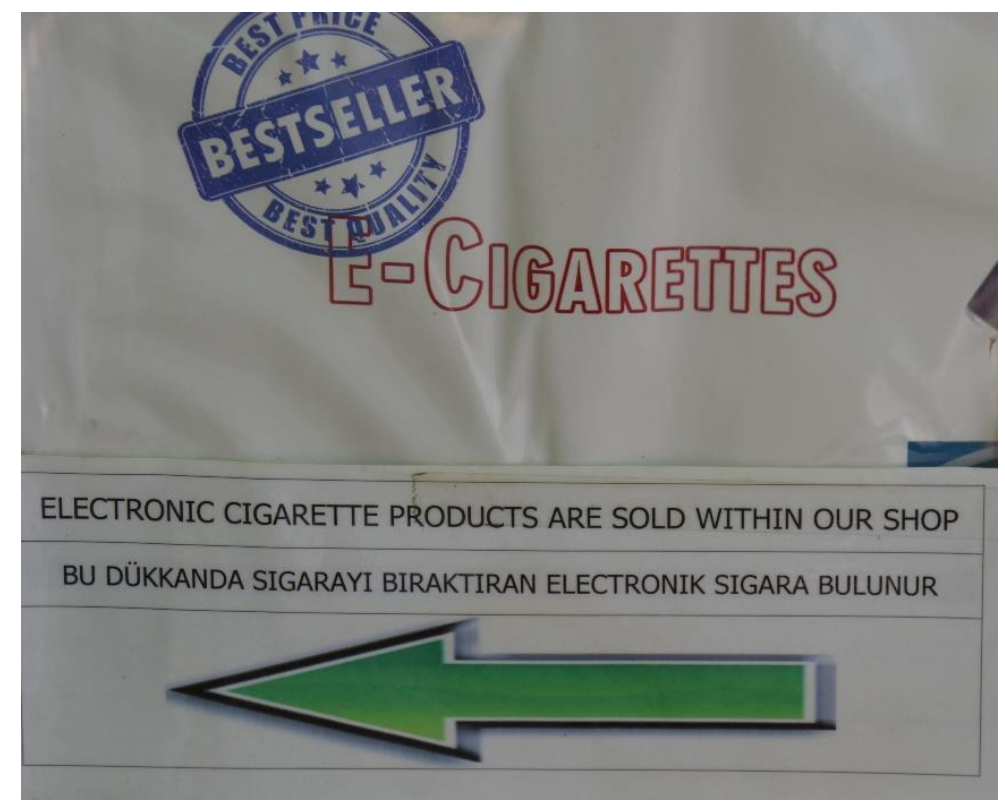

Figure 11b. Advertisement board at Ledra Street in Greek-Cypriot community.

More instances of Greek language usage have been identified in the marketplace of the Turkish-occupied area. Most signs were temporary and produced by the shopkeepers (Figures 12 and 13). The notifications in Figure 11 are placed on the window of a minimarket which is located very close to the Turkish checkpoint, making them visible as soon as one crosses the border. These signs inform the passers-by that they can buy traditional sweets. Three signs are in English, two in Greek and two in Turkish, targeting therefore various audiences. An interesting observation is that some of these signs contain spelling errors in Greek; for instance, ' $\kappa \alpha \rho v \delta$ ió $\pi \alpha \dot{\sigma} \sigma \alpha$ ' in Figure 12 reads 'walnut tree paste' instead of ' $\kappa \alpha \rho \delta \delta$ ó $\pi \tau \alpha$ ' 'walnut cake'. Also,

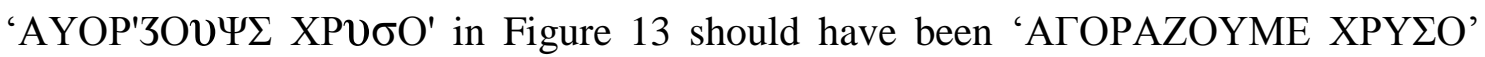


('WE BUY GOLD'). This indicates that the authors are not competent writers in Greek, yet they are making an attempt to target a Greek-speaking audience. These signs are inclusive and their main purpose is to advertise products and services. In these cases, ideologies of separation are somehow ignored as consumerism becomes more important.

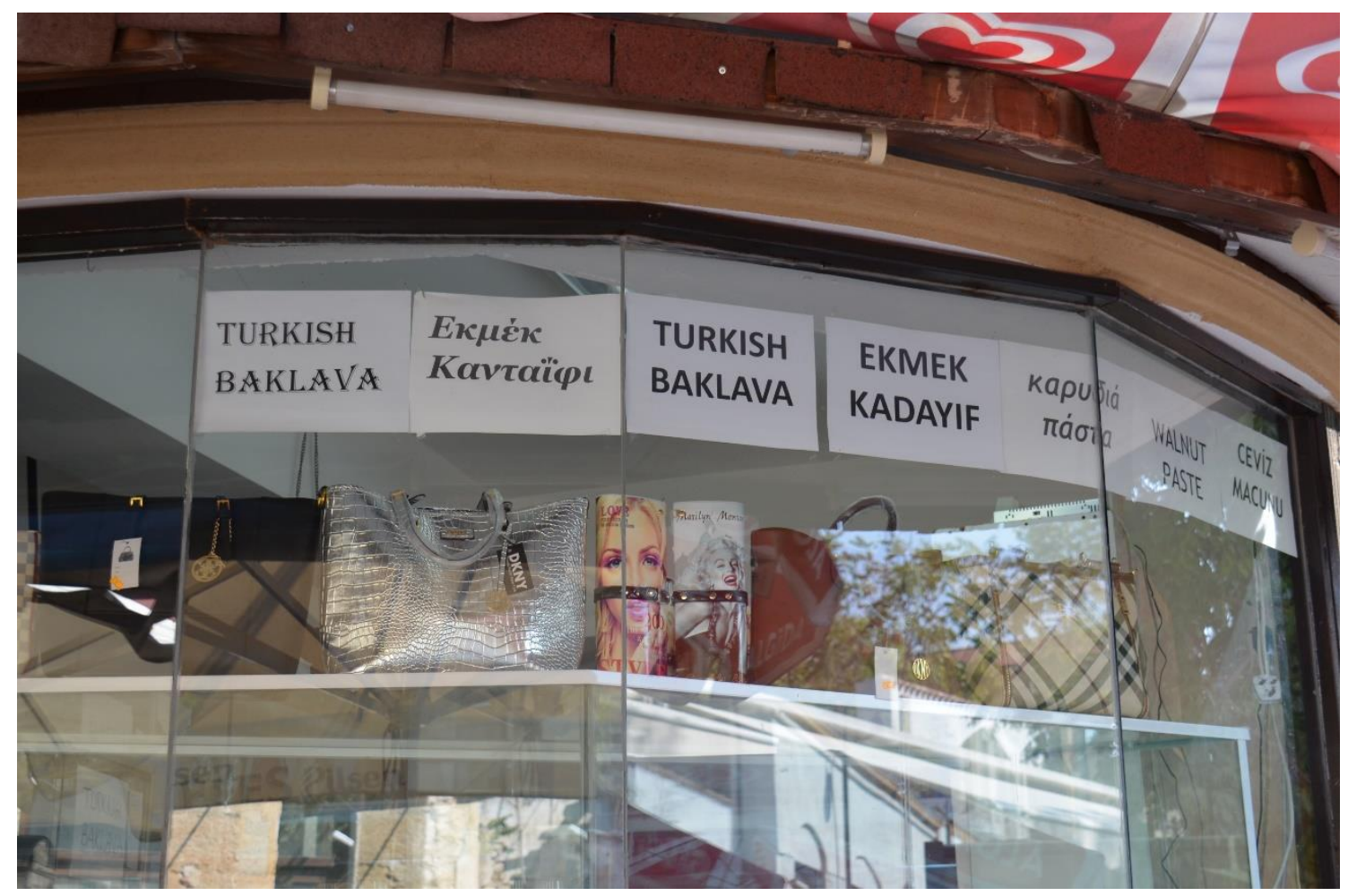

Figure 12. Signs advertising traditional sweets in Turkish-occupied area. 


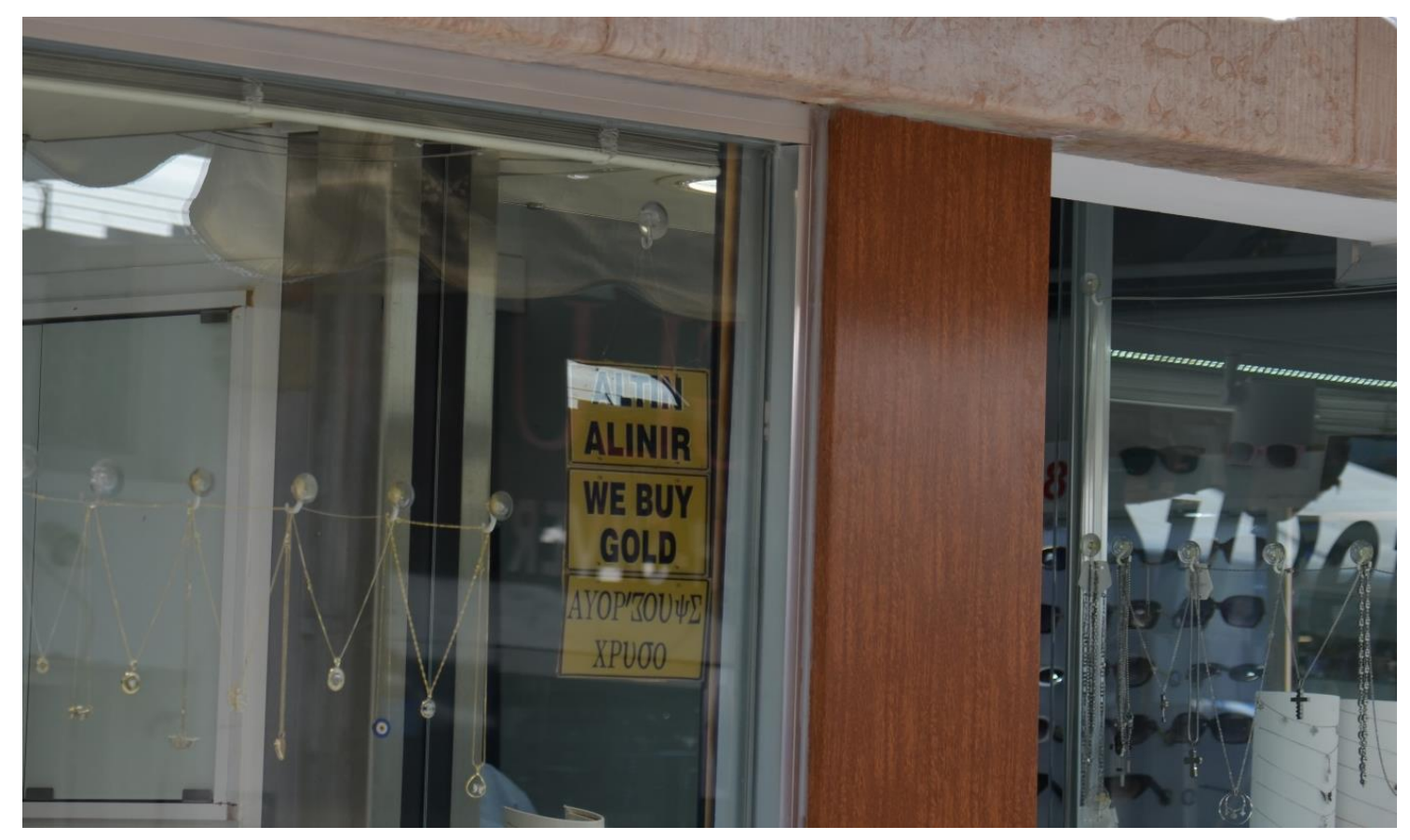

Figure 13. Sign on jewelry shop in Turkish-occupied area.

\section{Ephemeral signs}

The majority of posters in the Greek-Cypriot community were in Greek and/or English while not many have been identified in the Turkish-occupied area. Interestingly, a few instances of posters and stickers which contained both Greek and Turkish have been identified. The poster in Figure 14 was found in the Greek-Cypriot community, displayed on a wall, in a small side street off Ledra Street. It advertises a music event in the Turkish-occupied area called 'Anti-military Peace Operation'. Starting from the top, the poster provides information about the name, date, time and location of the event. The alignment is sometimes vertical and sometimes horizontal but in all cases 
Turkish is prioritised, followed by Greek. The image and the sentence that follows are significant as they project a strong message against conflict. The image shows soldiers playing musical instruments, dj-ing and taking photos instead of fighting and holding guns while the sentence in the middle of the poster encourages people to take photos, sing songs, fight for peace and go against the occupation. These features on this poster promote a discourse of integration, peace and unification which go against previous ideologies identified in the majority of signs discussed above.

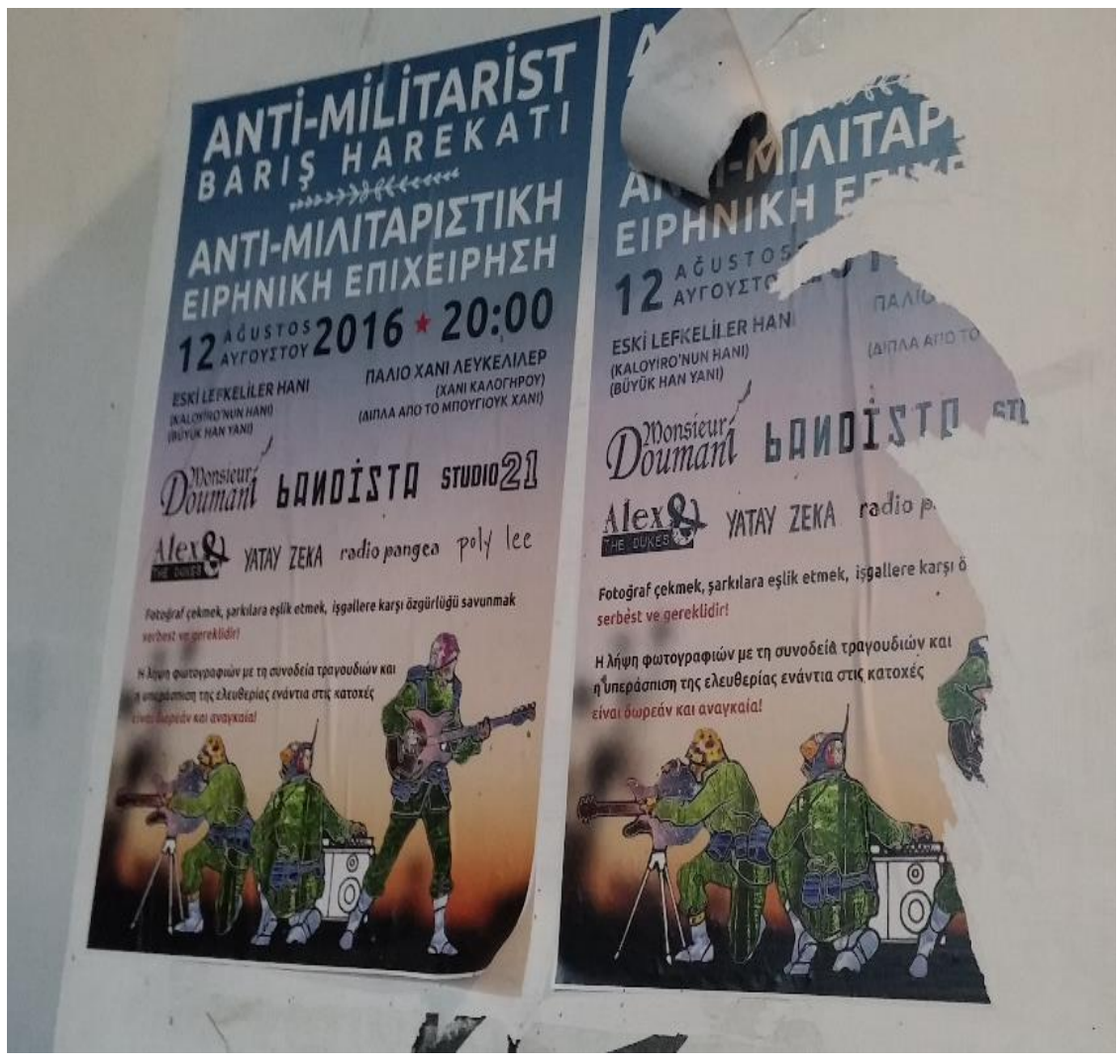

Figure 14. Turkish-Cypriot poster found in Greek-Cypriot area. 
The next ephemeral sign (Figure 15) is a sticker which advertises a festival this time in the Greek-Cypriot area. The pink sticker displays a Greek slang phrase ' $\mu$ óvov $\alpha \gamma \alpha ́ \pi \eta \rho \varepsilon ! '$ in big white letters. The choice of the Greek, its emplacement at the top and also the location where the festival is taking place indicate that the organisers of this event are Greek-Cypriots. The translation of the slang phrase is provided in brackets on the right-hand side, firstly in English (ONLY LOVE YO!) and then in Turkish (SADECE AŞK BE!). The font of the translations though is significantly smaller and less visible. For English-speakers this is not a major issue because all the information regarding the location, time and type of event are provided in English. The use of Turkish can be seen as an attempt of unification as Turkish-Cypriots are also invited to the event, nonetheless since the font is very small and hardly visible, this unification attempt is somehow hidden, in a similar manner with the advertising board containing Turkish discussed in Figure 11. The emplacement of this sign in the physical world is also interesting. The sticker was found in two locations: 1) on a pedestrian direction sign in a central square in the Turkish-occupied area, 2) on a public direction sign in the buffer zone. In both cases, this sticker projected a strong message about importance of love and peace and their emplacement in these specific locations further enhanced these ideologies.

Both ephemeral signs promote ideologies of unification and the mere intention to organise a common event for both communities and advertising it by emplacing the 
signs in the public space of the other community demonstrates some subtle movements from the general public towards integration and reunification.

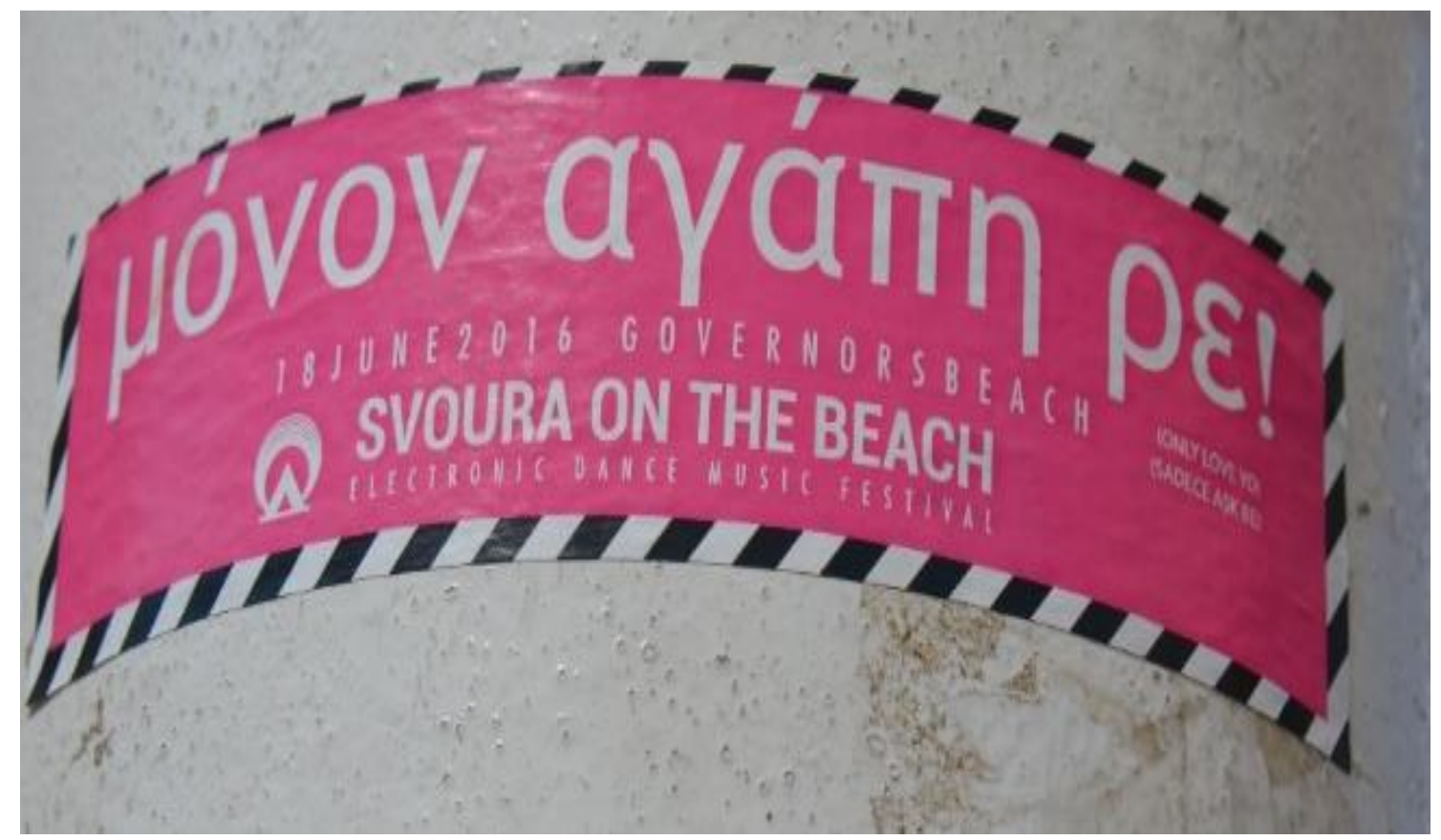

Figure 15. Music festival sticker.

During my fieldwork, various graffiti signs were identified in the Greek-Cypriot community and the buffer zone, but not many instances were found in the Turkishoccupied area. Figure 16 is a graffiti that contains only English but its location, lexical choice and visual aspects project a strong message in relation to conflict. This graffiti is located in the Greek-Cypriot community near the buffer zone. The unknown artist created this graffiti on the original bricked wall which was used to divide the two communities during the conflict. It displays the phrase 'Break down the wall' and the 
visual aspect shows a man wearing a hoodie, holding a hammer and breaking the wall. The graffiti in Figure 17 was found on an abandoned building in the buffer zone. The statement 'ONE CYPRUS' is written in English in black capital letters, requesting unification. Underneath this statement another person wrote 'or $\pi \varepsilon \lambda \lambda \alpha$ á $\rho \varsigma . . . '$ ('no nonsense'). The second component in the graffiti is interesting for two reasons. Firstly, the creator of the second sign initiates a dialogue between himself/herself and the producer of the first sign, supporting the desire for unification. Secondly, the phrase 'or $\pi \varepsilon \lambda \lambda \alpha \rho_{\rho} \varepsilon \varsigma_{. . .}$is in the Cypriot-Greek dialect, the variety that does not have a standard orthography and is rarely used for written purposes (see also Themistocleous 2010a, 2010b). This code choice here indicates that the creator of the second sign is GreekCypriot but also by using the dialect instead of Standard Modern Greek it indexes a strong local Greek-Cypriot identity, challenging also notions of normativity in written linguistic behavior (see also Tsiplakou 2017). Both examples of graffiti promote ideologies of peace and unification and these are further enhanced by their emplacement nearby the border and within the buffer zone, two areas which are politically and culturally contested. In the case of Figure 15, this is further enhanced by the creation of the graffiti on the original part of the dividing wall, further emphasising the importance of emplacement. 


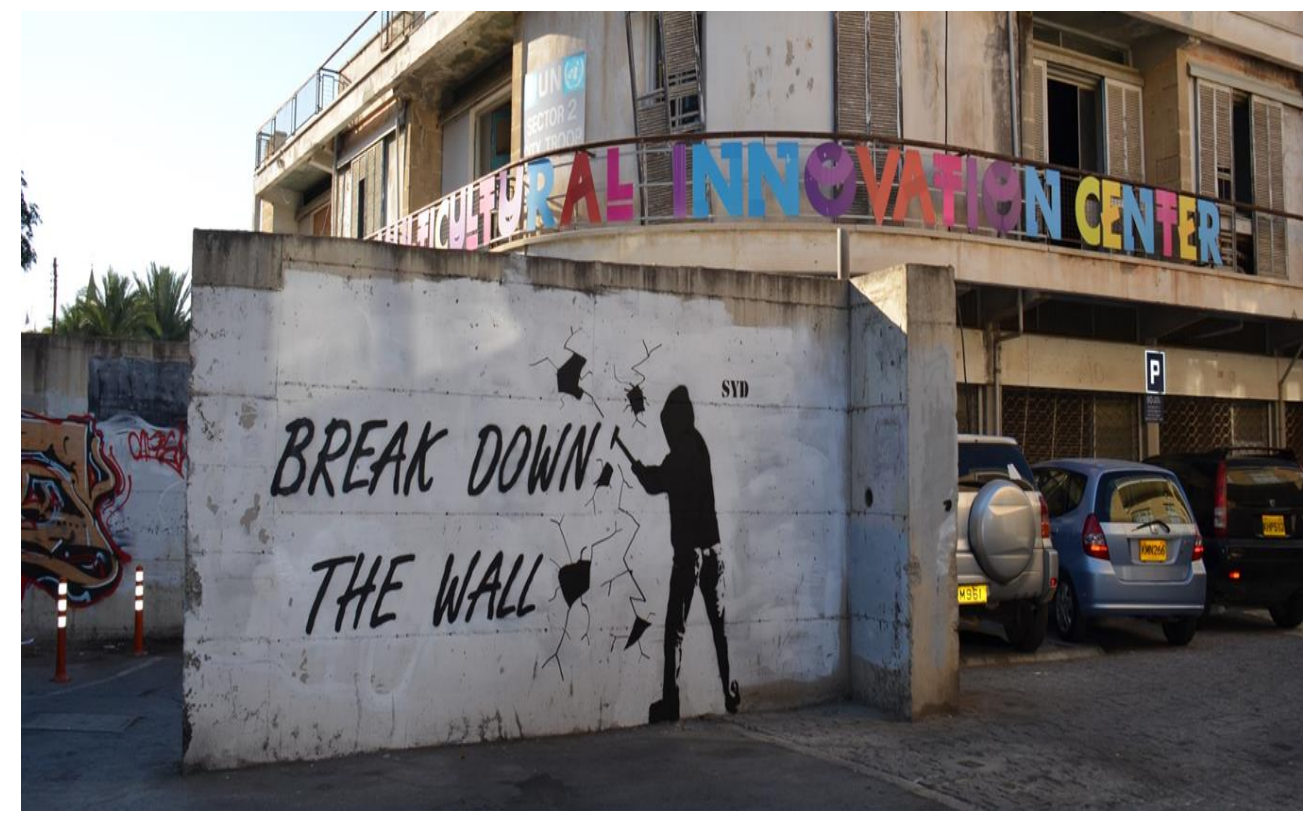

Figure 16. Graffiti in the Greek-Cypriot community.

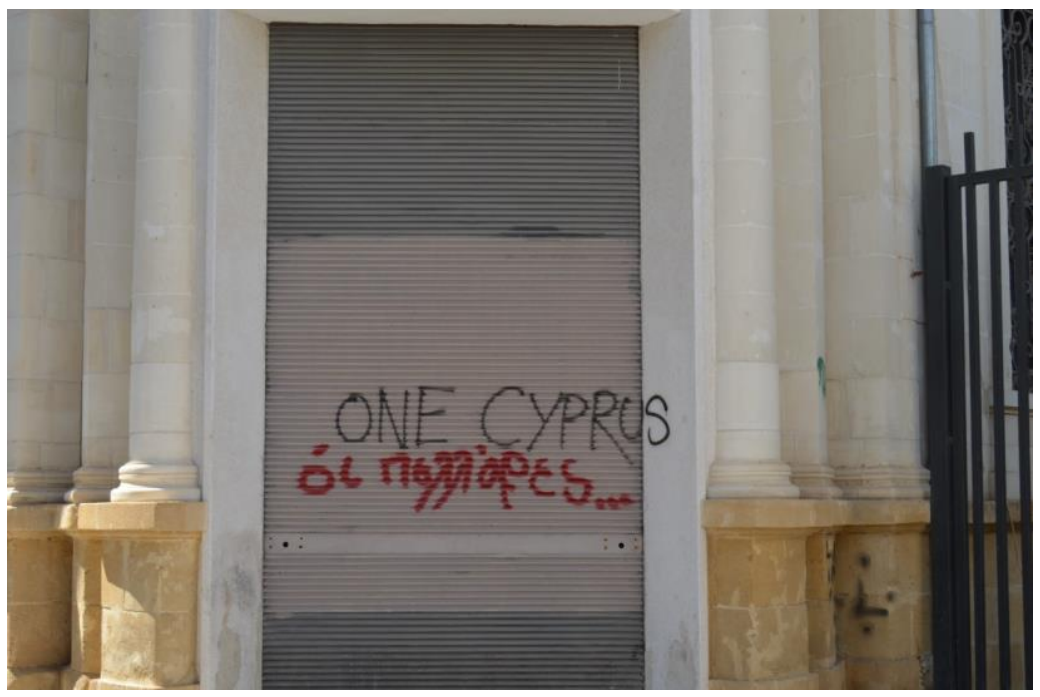

Figure 17. Graffiti in the buffer zone. 


\section{Conclusion}

By adopting the geosemiotics framework this study explored the visibility or exclusion of Greek, Turkish and English in the public space near Nicosia's border; an area characterised by division and conflict. I looked at both informational and symbolic functions projected by the display or absence of each language on public signage, focusing also on sign emplacement, spatial arrangements, images, communicative intents, target audience and indexicality. Unlike previous quantitative studies, this study provides deeper understanding of how the public space in this multilingual area is socially constructed and uncovers cultural, historic and political ideologies and issues of identity.

The findings indicate that the area under examination is a liminal space, where different types of multilingual signage index varying voices and ideologies. First of all, a good deal of Nicosia's public space is designed by political and institutional priorities. Street name signs for instance are produced by the local authorities following their own language policies and they tend therefore to exclude the language of 'the other'. This indexes not only territorial limits and language boundaries but also restricts the target audience and as a result promotes distinct cultural and national identities. This reflects historical and political ideologies of division and alienation. The marketplace in the Greek-Cypriot community also follows this pattern and manifests the same ideology. Linguistic gatekeeping is at play as the visibility of Turkish and therefore the attraction 
of Turkish-speaking clientele does not seem to be in the interest of local businesses. This is different in the marketplace of the Turkish-occupied area which is less developed and needs economic boost. Signs that contain Greek seem to go against ideologies of separation, as consumerism becomes imperative. Signs placed in the buffer zone tell a different story. Because this zone is controlled by the UN and its development was funded by the EU, the languages of both ethnic groups are visible in top-down signs, which indexes ideologies of tolerance. Yet, the emplacement of codes within the signs often reflects not only local language policies, but also historical and political power relations between the two ethnic communities. Finally, we have seen that some ephemeral signs and graffiti promote integration and index ideologies of peace and unification.

Looking at the spatialisation processes and the interplay of signs in this contested area, the findings demonstrate that wider social, historical and political aspects have led to the configuration of this public space. With the opening of the border the linguistic landscape of this area has changed to accommodate the fact that people from both ethnic communities now move across the border. However, even if people have become more mobile and find it easier to cross the border that for 30 years hindered their movement, the public space near Nicosia's border still indexes strong ethnic affiliations and loyalties (see also Newman 2006: 147). While some ideologies are deeply-rooted into historical and political events persist, we have also seen that 15 
years after the opening of the border new ideologies start to surface. This creates a dialogue between the two local governments which battle for political legitimization and, at least, some members of the public who start to promote integration and peace.

In order to better understand how Nicosia's border area is socially constructed it is also necessary to explore how social actors (e.g. ordinary people who live, work and shop in this area) experience and perceive this space. An ethnographic investigation can shed light on ordinary people's individual and personal ideologies and their attitudes towards the multilingual landscape of this area which is characterised by long-term conflict. Greater understanding of the social construction of public space, its production and the general public's perception and experience of it will help inform language policies and practices at this crucial time of peace negotiations for the Republic of Cyprus. 


\section{References}

Akçal1, Emel. 2011. “Getting real on fluctuating national identities: Insights from Northern Cyprus.” Antipode 43(5): 1725-1747.

Antoniou, Kyriakos and Napoleon Katsos. 2017. "The effect of childhood multilingualism and bilectalism on implicature understanding." Applied Psycholinguistics 38, 787-833.

Ben-Rafael Eliezer, Elana Shohamy, and Barni Monica. 2010. "Introduction: An approach to an 'Ordered Disorder'”. In Linguistic Landscape in the city, edited by Shohamy Elana, Eliezer Ben-Rafael and Monica Barni, xi-xxviii. Bristol: Multilingual Matters.

Ben-Rafael, Eliezer, Elana Shohamy, Amara Muhammad Hasan, and Nira TrumperHecht. 2006. "Linguistic Landscape as symbolic construction of the public space: The case of Israel." International Journal of Multilingualism 3(1): 7-30.

Blommaert, Jan. 2013. Ethnography, superdiversity and Linguistic Landscapes: Chronicles of complexity. Bristol: Multilingual Matters.

Bryant, Rebecca. 2010. The Past in Pieces: Belonging in the New Cyprus. Philadelphia: University of Pennsylvania Press.

Carvalho, Ana. 2014. "Towards a sociolinguistics of the border." International Journal of the Sociology of Language 227: 1-7. 
Charalambous, Panayiota, Constadina Charalambous, and Ben Rampton. 2017. "Desecuritizing Turkish: Teaching the language of a former enemy, and intercultural language education.” Applied Linguistics 38(6): 800-823.

Coupland, Nikolas. 2010. "Welsh Linguistic Landscapes 'From Above' and 'From Below"'. In Semiotic landscapes: Language, image, space, edited by Adam Jaworski and Crispin Thurlow. 77-101. London: Continuum.

CYSTAT (Statistical Service of the Republic of Cyprus) (2011) Population and Social Conditions: Census 2011. Nicosia: CYSTAT.

Eracleous, Natalya and Aneta Pavlenko. 2012. "Russian in linguistic landscape of Cyprus: Commodification of affect?" Paper presented at the $19^{\text {th }}$ Sociolinguistics Symposium, Freie Universität Berlin.

Gorter, Durk. 2006. Linguistic Landscape: A new approach to multilingualism. Buffalo: Multilingual Matters.

Hadjioannou, Xenia, Stavroula Tsiplakou, and Matthias Kappler. 2011. "Language policy and language planning in Cyprus." Current Issues in Language Planning 12 (4): 503-569.

Hanauer, David. 2011. "The discursive construction of the separation wall at Abu Dis: Graffiti as political discourse." Journal of Language and Politics 10 (3): 301-321.

Innes, Alexandria. 2017. "Mobile diasporas, postcolonial identities: The Green Line in Cyprus.” Postcolonial Studies 20(3): 353-369. 
Jaworska, Sylvia, and Christiana Themistocleous. 2018. "Public discourses on multilingualism in the UK: Triangulating a corpus study with a sociolinguistic attitude survey." Language in Society, 47 (1): 57-88.

Jaworski, Adam, and Crispin Thurlow. 2010. Semiotic landscapes: Language, image, space. London: Continuum.

Johnstone, Barbara. 2004. "Place, globalization and linguistic variation." In Sociolinguistic variation: Critical reflections, edited by Carmen Fought, 65-83. New York: Oxford University Press.

Kallen, Jeffrey. 2010. “Changing landscapes: Language, space and policy in the Dublin Linguistic Landscape.” In Semiotic landscapes: Language, image, space, edited by Adam Jaworski and Crispin Thurlow, 41-58. London: Continuum.

Karageorghis, Jacqueline. 2011. Cyprus: There is an island. Nicosia: En Tipis Publications.

Karoulla-Vrikkis, Dimitra. 2010. "50 years of language policy in the Republic of Cyprus. Promotion of Greek, Cypriot or European identity?” In Republic of Cyprus 50 years: A painful path, edited by Crysostomos Perikleous, 130-157. Athens: Papazisi.

Karoulla-Vrikkis, Dimitra. 2013. "Public and commercial signs in Cyprus: Should language policy foster and identity?" In Language Policy and Planning in the 
Mediterranean World, edited by Marilena Karyolemou and Pavlos Pavlou, 210-224. Newcastle: Cambridge Scholars.

Karoulla-Vrikkis, Dimitra. 2016. "English as a Lingua Franca: The LL in Lidras and Onasagorou Street, Lefkosia, Cyprus.” In ELF: Pedagogical and Interdisciplinary Perspectives, edited by Natasha Tsantila, Jane Mandalios and Melpomeni Ilkos, 144153. Athens: Deree - The American College of Greece.

Karyolemou, Marilena. 2003. “'Keep your language and I will keep mine': Politics, language, and the construction of identities in Cyprus." In At War with Words, edited by Mirjana Dedaić and Daniel Nelson, 359-384. Berlin: Mouton de Gruyter.

Kasanga, Luanga. 2015. "Semiotic landscape, code choice and exclusion." In Conflict, exclusion and dissent in the Linguistic Landscape, edited by Rani Rubdy, and Selim Ben Said, 123-144. Basingstoke: Palgrave Macmillan.

Kizilyürek, Niyazi, and Sylvaine Gautier-Kizilyürek. 2004. "The politics of identity in the Turkish-Cypriot community and the language question." International Journal of the Sociology of Language 168: 37-54.

Kress, Gunther, and Theo van Leeuwen. 1996. Reading images: The grammar of visual design. London: Routledge. 
Lado, Beatriz. 2011. "Linguistic Landscape as a reflection of the linguistic and ideological conflict in the Valencian community." International Journal of Multilingualism 10, 1-22.

Landry, Rodrigue, and Richard Bourhis. 1997. "Linguistic Landscape and ethnolinguistic vitality: An empirical study." Journal of Language and Social Psychology 16(1): 23-49.

Lefebvre, Henri 1991. The production of space. Oxford: Blackwell.

Lou, Jackie Jia. 2016. The Linguistic Ladnscape of Chinatown: A Sociolinguistic Ethnography. Bristol: Multilingual Matters.

Mallinson, William. 2009. A modern history of Cyprus. London: I. B. Tauris.

Marangou, Ana, and Andreas Coutas. 2011. Nicosia: The history of the city. Nicosia: Cassoulides Masterprinters.

Marten, Heiko, Luk Van Mensel, and Durk Gorter. 2012. Studying minority languages in the Linguistic Landscape. In Minority languages in the Linguistic Landscape, edited by Durk Gorter, Heiko Marten, and Luk Mensel, 1-18. Basingstoke: Palgrave Macmillan.

Muth, Sebastian. 2014. "Linguistic Landscapes on the other side of the border: Signs, language and the construction of cultural identity in Transnistria." International Journal of the Sociology of Language 227: 25-46. 
Newman, David. 2006. "The lines that continue to separate us: Borders in our 'borderless' world." Progress in Human Geography 30 (2): 143-161.

Nicolaou, Anna, Antigoni Parmaxi, Salomi Papadima-Sophocleous, and Dimitrios Boglou. 2016. "Language education in a multilingual city: The case of Limassol." London Review of Education 14 (2): 174-185.

Norris, Sigrid and Rodney, Jones. 2005. Discourse in Action: Introducing Mediated Discourse Analysis. Oxon: Routledge.

Paasi, Anssi. 1999. "Boundaries as social practice and discourse: The Finnish-Russian border." Regional Studies 33(7): 669-680.

Papen, Uta. 2012. “Commercial discourses, gentrification and citizens' protest: The Linguistic Landscape of Prenzlauer Berg, Berlin.” Journal of Sociolinguistics 16(1): $56-80$.

Pavlenko Aneta 2017. "Russian-friendly: How Russian became a commodity in Europe and beyond." International Journal of Bilingual Education and Bilingualism 20(4): 385-403.

Pavlenko, Aneta. 2009. "Language conflict in post-Soviet Linguistic Landscapes." Journal of Slavic Linguistics 17 (1-2): 247-274.

Pavlou, Pavlos. 2004. Greek dialect use in the mass media in Cyprus. International Journal of the Sociology of Language 168: 101-118. 
Pennycook, Alastair. 2010. "Spatial narrations: Graffscapes and city souls.” In Semiotic Landscapes: Language, image, space, edited by Adam Jaworski and Crispin Thurlow, 137-150. London: Continuum.

Pennycook, Alastair, and Emi Otsuji. 2015. "Making scents of the landscape." Linguistic Landscape 1(3): 191-212.

Rubdy, Rani, and Selim, Ben-Said. 2015. Conflict, exclusion and dissent in the Linguistic Landscape. Basingstoke: Palgrave Macmillan.

Scollon, Ron, and Suzie, Wong Scollon. 2003. Discourse in place: Language in the material world. London: Routledge.

Sebba, Mark. 2010. "Discourses in transit”. In Semiotic landscapes: Language, image, space, edited by Adam Jaworski and Crispin Thurlow, 59-76. London: Continuum, pp. 59-76.

Shohamy, Elana. 2006. Language policy: Hidden agendas and new approaches. New York: Routledge.

Shohamy, Elana, Eliezer Ben-Rafael, and Monica Barni. 2010. Linguistic Landscape in the city. Bristol: Multilingual Matters.

Shohamy, Elana, and Shoshi Waksman. 2009. "Linguistic Landscape as an ecological arena: Modalities, meanings, negotiations, education." In Linguistic Landscape: 
Expanding the scenery, edited by Elana Shohamy and Durk Gorter, 313-331. Oxon: Routledge.

Themistocleous, Christiana. 2010a. “'Bananas and other fruits': Language and identity in PIN's cartoons." Paper presented at the $18^{\text {th }}$ Sociolinguistics Symposium, University of Southampton, UK.

Themistocleous, Christiana. 2010b. Writing in a non-standard Greek variety: Romanized Cypriot Greek in online chat. Writing Systems Research 2(2): 155-168.

Themistocleous, Christiana. 2015. Digital code-switching between Cypriot and Standard Greek: Performance and identity play online. International Journal of Bilingualism 19(3): 282-297.

Tofallis, Kypros. 2016. A history of Cyprus. London: Greek Institute.

Trumper-Hecht, Nira. 2009. "Constructing national identity in mixed cities in Israel: Arabic on signs in the public space of Upper Nazareth." In Linguistic Landscape: Expanding the scenery, edited by Elana Shohamy and Durk Gorter, 238-252. London: Routledge.

Tsiplakou, Stavroula. 2017. Urban language landscapes and dialects: Places in Nicosia [in Greek]. In Studies in Greek Linguistics 37: Proceedings of the Annual Meetings of the Department of Linguistics, edited by Despina Papadopoulou and Alexandros Tantos, 727-746. Thessaloniki: Institute of Modern Greek Studies.

Tuan, Yi-Fu. 1977. Space and Place. Minneapolis: University of Minnesota Press. 
Tum, Danyal Oztas, Naciye Kunt, and Mehmet Kunt. 2016. "Language learning in conflictual contexts: A study of Turkish-Cypriot adolescents learning Greek in Cyprus." Language, Culture and Curriculum 29(2): 207-224.

United Nations Development Programme, 2012. Nicosia master plan. Available at: http://www.undppff.org/index.php?option=com_content\&task=view\&id=80\&Itemi $\underline{\mathrm{d}=140}$ (accessed 19 August 2017).

Watt, Dominic, and Carmen, Llamas. 2014. Language, borders and identity. Edinburgh: Edinburgh University Press. 


\footnotetext{
i A note on terminology: The term 'border' usually suggests a legal border. However, according to Innes (2017), the Green Line in Cyprus is not a conventional border. The UN-controlled buffer zone (Green Line) was first established in 1964 and, after the ceasefire in 1974, a dividing line was implemented, separating the two ethnic communities. The term dividing line was widely used to refer to the fact that the island was bisected into the Republic of Cyprus and the de facto state of TRNC, recognised only by Turkey (Innes 2017). Bryant (2010) argues that the ease of movement restrictions in 2003 which involved normal rituals of immigration, such as the physical act of crossing a border to visit the 'other side' by showing one's passport, made the idea of 'border' more real to Greek-Cypriots. To this date, the border is not given official status as a European border, because such status would require recognising the TRNC as an official, independent state (Innes 2017). According to Innes (2017: 364): 'The line is therefore a border without being a border'.

ii Small minorities known as 'enclaves' remained in the 'other side'. Also, an important number of settlers/immigrants from Turkey inhabited the north part of the island after the division (Hadjioannou et al, 2011).

iii According to a survey conducted by the International Peace Research Institute, 699,673 people crossed the border in 2008 only (United Nations Development Programme, 2017).

iv Despite the lack of standard official orthography, writing in the Cypriot-Greek dialect is evident in local literature and poetry, traditional songs, advertisements (Pavlou 2004), political cartoons (Themistocleous 2010a) and social media (Themistocleous 2010b; 2015). The presence and use of the Cypriot-Greek dialect is not usually expected in public space as this is mainly an oral variety (Karoulla-Vrikkis 2013).
} 